\title{
THE IMPACT OF DECISIONS TO OUTSOURCE THE INTERNAL AUDIT FUNCTION IN SOUTH AFRICA
}

\author{
Elmarie Papageorgiou* \\ University of the Witwatersrand \\ Elmarie.Papageorgiou@wits.ac.za \\ Nirupa Padia\# \\ University of the Witwatersrand \\ Nirupa.Padia@wits.ac.za \\ Yaeesh Yasseen+ \\ University of the Witwatersrand \\ yaeesh.Yasseen@wits.ac.za
}

Received: June 2012
Accepted: July 2013

\begin{abstract}
Organisations are constantly striving to maximise shareholder wealth by improving the effectiveness and efficiency of operations. Since the early 1980s, there has been an emerging trend to outsource functions considered to be non-core. These trends have now moved into the internal audit sphere, a function that was previously maintained in-house. Using survey data collected from organisations in the South African private and public sectors, the degree of internal audit outsourcing, the rationale behind organisations' outsourcing decisions, the types of internal audit services provider, the perceived status of in-house internal auditing and perceptions of independence of outsourced internal audit functions were determined. It was noteworthy that no significant differences were observed between sectors with regard to interaction with external auditors and threats to independence. The biggest difference appears to be that private companies chose a "Big 4" accounting firm more often than the government sector did. This study contributes to the existing body of knowledge and bridges the gap between theory and practice by highlighting the impact that the decision to outsource has had on the South African internal audit function.
\end{abstract}

Keywords

Decisions; independence; internal audit function; outsourcing; perceptions; private and public sectors; South Africa

\footnotetext{
*Prof Elmarie Papageorgiou is an associate professor at the School of Accountancy, University of the Witwatersrand, South Africa.

\#Prof Nirupa Padia is an associate professor at the School of Accountancy, University of the Witwatersrand, South Africa. +Mr Yaeesh Yasseen is a senior lecturer at the School of Accountancy, University of the Witwatersrand, South Africa.
} 


\section{INTRODUCTION}

Internal auditing as a profession on the global landscape is relatively new. In South Africa the profession was established in 1964 with the formation of the Institute of Internal Auditors South Africa (IIASA). However, the Institute only began to grow in the South African market during the 1980s. Academic and professional research into the practice of internal auditing has been fairly sporadic and, consequently, most of the research is exploratory. This study includes the iKUTU Report (IIASA, 2010), which was published by the Institute of Internal Auditors in 2010.

Over the past two decades, the South African economy has faced many challenges, the first being the transition from a racist regime to one where all stakeholders of the economy can participate equally. This in itself posed major challenges, and the first King Report on corporate governance $(I 0 D, 1994)$ aimed to educate these new stakeholders about being a corporate citizen and how to fulfil their new-found responsibilities. Secondly, the past two decades have seen the fall of large corporations, both locally and abroad, such as Enron, LeisureNet and Barings Bank, which shook the corporate world to its core. As a result, specialist skills and individuals were called for to protect the integrity of information-reporting in the economy. Consequently, internal auditing as a profession was placed in the spotlight and governance reports such as the King Code for corporate governance (IOD, 1994) called on internal auditing to deliver. In the words of Judge Mervin King, chairperson of the King Commission, from the "backroom into the boardroom" the profession needed to evolve and assist management in the areas of risk, control and governance. For South Africa this was not easy, as the post-segregated economy lacked the skills needed to resource itself.

The study by Selim and Yiannakas (2000), which was adapted to a comparative study in the South African context, investigates the impact that the decision to outsource the internal auditing function has had on South African private and public sector organisations in terms of establishing the reasoning behind this outsourcing decision, examining the impact this decision has had on auditors' independence (both internal and external) and on the quality of the internal audit service. However, it was not until the 1940s that the practice of internal auditing began to assume an important role in organisational strategy and management, and the professionalisation of internal auditing has continued steadily since then, with chapters of the Institute of Internal Auditors (IIA) (the recognised authority and principal educator of the internal auditing professions) having been established around the world (Castanheira, Rodrigues \& Craig 2009:79; IIA, 2011).

Recent changes in corporate governance in South Africa have affected the strategic directions taken by most organisations. As a result, the King code for corporate governance recommends the establishment of an internal audit function as a benchmark for best business practice (IOD, 2009). Accordingly, the manner in which a company manages the quality and costs of internal audit services is critical to the fulfilment of its responsibility to maintain a sound governance system (Carey, Subramanium \& Ching, 2006:12). There can be no doubt that as long as outsourcing initiatives get closer to the organisation's core and to activities that are at the centre of its future success, the risks involved will increase (Selim \& Yiannakas, 2000:1). 


\section{LITERATURE REVIEW}

Espino-Rodriguez and Padrón-Robaina (2006:50) state that the term "outsourcing" was coined in the late 1980s in relation to the subcontracting of information systems. As a result, the majority of sources identify outsourcing with the function of information systems. However, according to Espino-Rodriguez and Padrón-Robaina (2006:51), the term "outsourcing" has also been applied to other types of function or activity. The most significant definitions of outsourcing that have emerged from the literature are listed in TABLE 1.

\section{TABLE 1: A chronological review of the different definitions of outsourcing}

\begin{tabular}{|c|c|}
\hline Harrigan (1985) & $\begin{array}{l}\text { A variety of "make or buy" decisions to obtain the supplies of } \\
\text { materials and services necessary for producing the organisation's } \\
\text { goods and services. }\end{array}$ \\
\hline $\begin{array}{l}\text { Loh and Venkatraman } \\
\text { (1992) }\end{array}$ & $\begin{array}{l}\text { External vendors' provision of the physical and/or human resources } \\
\text { associated with the user organisation's information technology } \\
\text { infrastructure. }\end{array}$ \\
\hline Quinn and Hilmer (1994) & $\begin{array}{l}\text { External acquisition of activities, including those traditionally } \\
\text { considered an integral part of any firm, provided that they do not } \\
\text { form part of the firm's core capabilities. }\end{array}$ \\
\hline $\begin{array}{l}\text { Ventura (1995) cited } \\
\text { Espino-Rodriguez \& Padrón- } \\
\text { Robaina (2006:51) }\end{array}$ & $\begin{array}{l}\text { Exchange relationships with independent firms in terms of which } \\
\text { stable cooperation agreements can be established. }\end{array}$ \\
\hline Lei and Hitt (1995) & $\begin{array}{l}\text { The act of trusting in external capabilities and skills for the } \\
\text { manufacture of determined production components and other } \\
\text { activities that have added value (often capital intensive). }\end{array}$ \\
\hline $\begin{array}{l}\text { Rothery and Roberson } \\
\text { (1996) }\end{array}$ & $\begin{array}{l}\text { The act of turning to an external organisation to perform a function } \\
\text { previously performed in-house. It entails the transfer of the planning, } \\
\text { administration and development of the activity to an independent } \\
\text { third party. }\end{array}$ \\
\hline $\begin{array}{l}\text { Casani, Luque, Luque and } \\
\text { Soria (1996) cited in } \\
\text { Espino-Rodriguez and } \\
\text { Padrón-Robaina (2006:51) }\end{array}$ & $\begin{array}{l}\text { Long-term link related to the development of determined activities } \\
\text { or tasks that are not essential to the firm by specialised } \\
\text { professionals, who, in time, become strategic partners. }\end{array}$ \\
\hline Blumberg (1998) & $\begin{array}{l}\text { Process of making contracts with a third party to handle a part of the } \\
\text { client firm's business. }\end{array}$ \\
\hline $\begin{array}{l}\text { Sacristán (1999) cited in } \\
\text { Espino-Rodriguez and } \\
\text { Padrón-Robaina (2006:51) }\end{array}$ & $\begin{array}{l}\text { Collaboration agreement between different types of firm in which one } \\
\text { firm is a specialist in technology and makes a significant contribution } \\
\text { to the other by providing physical and/or human resources during a } \\
\text { certain period in order to attain a determined objective. }\end{array}$ \\
\hline Greaver (1999) & $\begin{array}{l}\text { The act of an organisation transferring periodic internal activities } \\
\text { and decision-taking to external suppliers through contracts. }\end{array}$ \\
\hline Gilley and Rasheed (2000) & $\begin{array}{l}\text { The substitution of activities performed in-house by acquiring them } \\
\text { externally, although the firm has the necessary management and }\end{array}$ \\
\hline
\end{tabular}




$\begin{array}{ll} & \begin{array}{l}\text { financial capabilities to develop them internally. It is also an } \\ \text { abstention from performing activities in-house. }\end{array} \\ \begin{array}{ll}\text { Campos (2001) cited in } \\ \text { Espino-Rodriguez and } \\ \text { Padrón-Robaina (2006:51) }\end{array} & \begin{array}{l}\text { It consists of contracting an external supplier to perform a task } \\ \text { previously executed by the organisation itself, and may also even } \\ \text { involve new activities. }\end{array} \\ \begin{array}{ll}\text { Bailey, Masson and Raeside } \\ \text { (2002) }\end{array} & \begin{array}{l}\text { Handing over some or all of that particular activity and related } \\ \text { services to a third-party management in order to obtain the required } \\ \text { result. }\end{array} \\ \begin{array}{l}\text { Quélin and Duhamel (2003) } \\ \text { The operation of shifting a transaction previously governed internally } \\ \text { to an external supplier through a long-term contract, and involving } \\ \text { the transfer to the vendor. }\end{array} \\ \begin{array}{l}\text { McCarthy and Anagnostou } \\ \text { (2004) }\end{array} & \begin{array}{l}\text { Not only consists of purchasing products or services from external } \\ \text { sources, but also transfers the responsibility for business functions } \\ \text { and often the associated knowledge (tacit and codified) to the } \\ \text { external organisation. }\end{array} \\ \begin{array}{l}\text { Mol, Van Tulder and Beige } \\ \text { (2005) }\end{array} & \begin{array}{l}\text { The procurement of supplies from legally independent entities } \\ \text { (suppliers). }\end{array}\end{array}$

Source: Authors' analysis

The definitions in TABLE 1 can be classified into three categories: The first category of definitions deals with contractual theory and exchange theory with construction firms. The second category of definitions considers core competency theory and the outsourcing of nonstrategic services, while the third set of definitions encompasses knowledge management and contractual theory. Espino-Rodriguez and Padrón-Robaina (2006:52) acknowledge that there is a gap in the definitions and conclude that the most applicable definition for outsourcing that encompasses all three categories, and that should be used as the basis for outsourcing and the development of the methodology, is as follows:

Outsourcing is a strategic decision that entails the external contracting of determined nonstrategic activities or business processes necessary for the manufacture of goods or the provision of services by means of agreements or contracts with higher capability firms to undertake those activities or business processes, with the aim of improving competitive advantage (Espino-Rodriguez \& Padrón-Robaina, 2006:52).

Outsourcing decisions in the literature stem from two sources: from the desire to maximise resources and from politics. The objective of being in business is to maximise wealth, a notion that is substantiated by the theory of the firm by posing the question: If firms do not exist to maximise wealth, then why do firms exist at all? As the literature study confirmed, not all activities are outsourced, which leads to the question that still needs to be addressed: When, how and why should a firm outsource its internal audit function?

The main reasons for outsourcing are summarised from the above literature sources as follows:

- The outsourcing phenomenon has grown exponentially and does not only pertain to information systems. As firms become more globalised this trend will probably continue into the future. There is no evidence in the literature to predict otherwise.

- The outsourcing practice allows management to concentrate on the core functions of the company. It would therefore be attractive to outsource all ancillary functions. 
Core competency theory is a mechanism that organisations use to gain competitive advantage in terms of which they obtain specialised skills without any internal investment in these skills. This theory is supported by the resource-based view of the firm. Accordingly, aligning the organisation's purpose of attaining competitive advantage with resources and protecting competitive positions serves as a motivation to outsource functions that do not enhance the firm's competiveness, rather than devoting more resources to maintaining the function in-house (Gottschalk \& Solli-Sæther, 2005; Smith, Morris \& Ezzamel, 2005:4).

Transaction cost theory assists in examining a wide range of decision problems, such as outsourcing by combining economic theory with management theory in order to establish the optimal category of relationship a firm should develop with respect to its economic status in the market (Ngwenyama \& Bryson, 1997:352; Mclvor, 2000:25; Liang \& Huang, 1998:31).

Contractual theory is also important in this context as it provides a legislative framework in terms of which each party's obligations under the contract are specified. Every outsourcing contract has the purpose of facilitating exchange and preventing opportunistic gains (Gottschalk \& Solli-Sæther, 2005). Appropriate contractual arrangements can reduce the flexibility for promoting unfair gains, as well as serve as a deterrent in mitigating risk in this mutual relationship and guarding each party's trade secrets. Contracts agreed to under relational exchange theory allow parties to gain access to information that was not available before (Baker, Gibbons \& Murphy, 2002:39). In the outsourcing context, there is the risk that once the relationship has been terminated in the future, the party who shared the outsourcing skill may be left undercompensated.

Agency theory highlights the dilemma in agency relationships; that is, that the principal cannot authenticate whether or not the agent has acted in the principal's best interests. Moreover, in an internal outsourcing arrangement, a problem might arise if the principal and the agent do not adopt the same methodology to mitigate risk (Bahli \& Rivard, 2010:213; Eisenhardt, 1989:58: Adams, 1994:9). The underlying debate will always be whether the agent can be warranted to act in good faith on behalf of the principal.

The theory of the boundary of the firm illustrates the inherent impasse in terms of which individuals with expertise from time to time receive confidential information that could be used to create a comparative advantage. On the other hand, the stakeholder theory of the firm establishes economic relationships within a context of ethical management (Reed, 2002:168; Gottschalk \& Solli-Sæther, 2005).

Thus, the various economic theories of the firm offer valuable perspectives on a firm's decision to outsource. In conclusion, this was a hermeneutic discussion which is intended to lay down a preamble to the decision to outsource the internal auditing function in the context of the organisation as a whole. TABLE 2 explains and highlights both the risks involved and the rationale for outsourcing the internal auditing function.

The Code of Ethics of the International Federation of Accountants (IFAC), which has been adopted by the South African Institute of Chartered Accountants (SAICA), maintains that professional accountants in public practice must remain independent, and therefore should not undertake an engagement which would threaten this independence. 
TABLE 2: Rationale for and against outsourcing the Internal Audit Function

\begin{tabular}{|c|c|c|}
\hline & Perceived opportunities & Perceived risks \\
\hline $\begin{array}{l}\text { Internal } \\
\text { operational }\end{array}$ & $\begin{array}{l}\text { Dispose of functions that are difficult to } \\
\text { manage } \\
\text { The opportunity to offload unproductive or } \\
\text { unwanted employees } \\
\text { The inability of the in-house audit function } \\
\text { to fulfil the audit plan on time } \\
\text { The organisation's inability to retain (or } \\
\text { recruit) people with the necessary skills }\end{array}$ & $\begin{array}{l}\text { An insider will know the business's } \\
\text { operations better than outsiders, } \\
\text { leading to more } \\
\text { efficiencies/effectiveness } \\
\text { Information theft more likely } \\
\text { Managing contractors can be } \\
\text { difficult and can lead to poor } \\
\text { performance }\end{array}$ \\
\hline $\begin{array}{l}\text { Access to } \\
\text { quality } \\
\text { services }\end{array}$ & $\begin{array}{l}\text { Access to auditors with specialised skills } \\
\text { Can ensure high quality of service through } \\
\text { contract and targeting skills needed for } \\
\text { task at hand } \\
\text { Share risks of business failure resulting } \\
\text { from poor control systems } \\
\text { Accountability improved from having an } \\
\text { independent party review operations }\end{array}$ & $\begin{array}{l}\text { Competency from externals is } \\
\text { unknown } \\
\text { Internal auditors available when } \\
\text { needed } \\
\text { Internal audit services needed } \\
\text { regularly, not just on occasional } \\
\text { basis } \\
\text { Independence of external auditors } \\
\text { may be surrendered if performing } \\
\text { too many functions for company }\end{array}$ \\
\hline $\begin{array}{l}\text { Strategic } \\
\text { response to } \\
\text { competition }\end{array}$ & $\begin{array}{l}\text { Cost savings that would result compared to } \\
\text { in-house auditor } \\
\text { Improve company focus or strategy } \\
\text { Respond to fundamental business climate } \\
\text { change } \\
\text { Support for global and/or geographic } \\
\text { initiatives }\end{array}$ & $\begin{array}{l}\text { Anticipated cost savings may be } \\
\text { overrated } \\
\text { "Core" functions should not be } \\
\text { outsourced or strategic position will } \\
\text { be lost }\end{array}$ \\
\hline $\begin{array}{l}\text { Managers' } \\
\text { perceptions of } \\
\text { services and } \\
\text { service } \\
\text { availability }\end{array}$ & $\begin{array}{l}\text { The presence of a large number of internal } \\
\text { audit providers in the market } \\
\text { The high rate of other organisations' } \\
\text { success when they outsourced their } \\
\text { internal auditing functions } \\
\text { Impartiality of an outside contractor } \\
\text { It is a core function of business }\end{array}$ & $\begin{array}{l}\text { Business will lose the benefit of } \\
\text { their own internal audit (or related) } \\
\text { management operations if } \\
\text { outsourced }\end{array}$ \\
\hline
\end{tabular}

Source: Van Peursem and Jiang (2008:25)

The Companies Act 71 of 2008 does not prohibit the provision of both internal and external audit services by the same audit firm; however, in terms of section 94(7)(e): "The audit committee of a company has to determine the nature and extent of any non-audit services that the auditor may provide to the company and to pre approve any proposed agreement with the auditor for the provision of non audit services to the company" (SAICA, 2011). The onus to evaluate the independence of the auditors and approve the provision of internal audit work by the audit firm is therefore on the company's audit committee.

To ensure investor confidence, auditors should be constantly aware of factors that affect the audit environment and which could influence or harm their independence. For instance, over the past few years, revenue from non-audit services has become increasingly important as firms 
seek to increase their profitability (Arnold, Bernardi \& Neidermeyer, 1999:45). These non-audit services include "investment banking and other capital-raising activities; strategic planning and operational consulting services; assistance in finding business partners or acquisition candidates; assistance in gaining regulatory approval for major transactions; outsourcing services such as internal audit and tax departments and other traditional management activities" (Sutton, 1997:88). As these types of relationship between clients and auditors increase, firms may become dependent on the revenue from these non-audit services (Arnold et al., 1999:45).

The IIA (Geiger, Lowe, \& Pandy, 2002:22) maintains that a clear conflict of interest exists when the certified public accounting (CPA) firm that performs the external audit also has primary responsibility for the internal audit. The IIA asserts that under such an arrangement the CPA firm becomes an indirect advocate of management assertions in the financial statements, thus possibly predisposing external auditors to serve corporate management rather than shareholders and investors. However, little evidence exists as to whether the users of financial statements believe that auditor independence or financial statement reliability is jeopardised when external auditors are engaged to perform internal audit activities (Geiger et al., 2002:22). The academic literature on contemporaneously performing the external audit and performing internal auditing services has not definitively shown the impact of these joint services on perceptions of independence (Hill \& Booker, 2004).

Carcello, Hermanson and Raghunandan (2005:70) examined factors associated with investment by US public companies in internal auditing. Data from a survey administered to the chief audit executives of mid-sized US public companies was supplemented with publicly available data. The total internal auditing budgets were found to be negatively related to the percentage of internal auditing that is outsourced. This study is important for the understanding of internal auditing services, and it allows companies to benchmark their outsourcing investment of internal auditing.

Allegrini, D'Onza, Paape, Melville and Sarens (2006:848) found that $61 \%$ of the responding internal audit departments did not use outsourcing or co-sourcing at the time of their study, but they expected to use more external service providers to some extent in the future. Goodwin and Kent's (2004) study suggested that Australian listed companies do not use internal auditing extensively. The study showed that size was a dominant driver of whether a company used internal auditing, suggesting that smaller companies do not regard it as cost-effective.

Van Peursem and Jiang (2008:19) explored patterns in and senior managers' reasons for their decisions to outsource or in-source internal auditing functions in New Zealand listed companies. The results of the Van Peursem and Jiang (2008:17) survey indicated that $43 \%$ still did not carry out any internal auditing. However, an IIA survey carried out in late 2003 showed that $80 \%$ of companies with a higher capitalisation that were listed on the Fortune 100 already had an internal auditing function. The Nasdaq also supports an internal auditing function as best practice (Harrington, 2004:45).

In the study by Cooper, Leung and Wong (2006:832) it was noted that $54.5 \%$ of companies rely fully on an in-house internal auditing function, while other companies outsource all or some of their internal auditing activities. Furthermore, $75 \%$ of those companies that outsource do so to an external auditor, which may have implications for perceptions about their independence. Hass, Abdolmohammadi and Burnaby (2006:6) state that "balancing the complex, competing demands of stakeholder needs with limited internal auditing function resources requires effective management by the Chief Audit Executive (CAE)". 
To determine the perceived status of both in-house and outsourced internal auditing functions, the iKutu Research Team examined the importance of certain attributes (competence, commitment, effective service delivery, flexibility and added value of internal auditing functions and whether they meet expectations). The value added by these functions in various activities was investigated and the frequency with which the recommendations of internal auditing functions were implemented by the participating companies was determined.

(Scale anschors: 1 = not important, 5 = extremely important)

Extremely important (mean $\geq 4.00)$; Very important $(3.00 \leq$ mean $<4.00)$;

Important $(2.00 \leq$ mean $<3.00)$; Reasonably important $(1.00 \leq$ mean $<2.00)$;

Not important $($ mean $<1.00)$

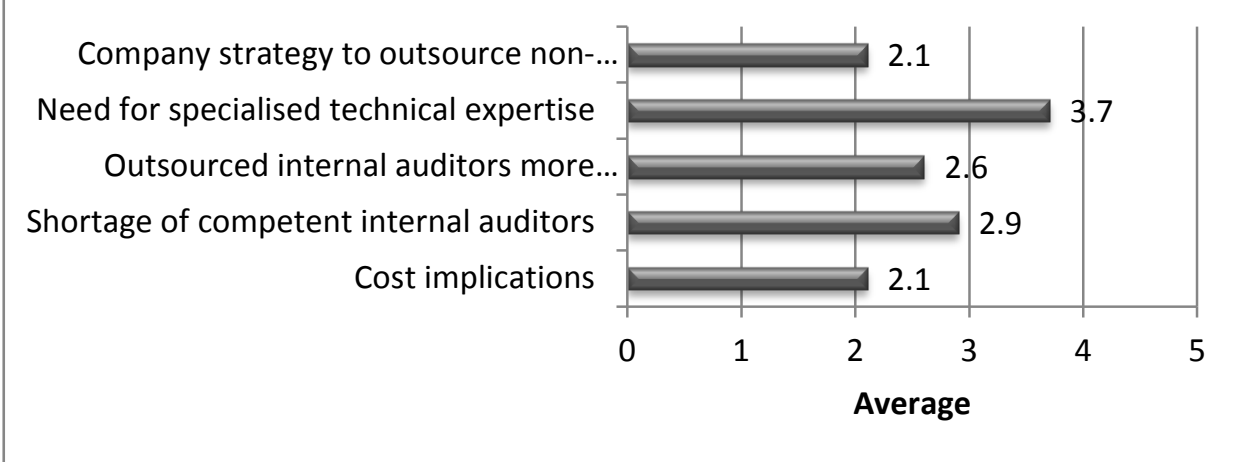

\section{FIGURE 1: Reasons for the decision to outsource the internal auditing function}

\section{Source: IIASA (2010:21)}

As FIGURE 1 reveals, respondents were extremely satisfied that their in-house internal auditing functions demonstrated compliance with each of the identified five attributes, as well as being extremely satisfied with the competence, commitment and flexibility to accommodate managements' needs displayed by their outsourced internal auditing functions.

\section{RESEARCH PROBLEMS AND METHODOLOGY}

The study discussed in this article followed the proven methodology used by Selim and Yianakkis (2000) for the internal auditing profession. As already mentioned, the outsourcing of the internal auditing function is in its infancy in South Africa. This has resulted in a gap in the research on the internal auditing function, especially with respect to the public and private sectors. The main aim of this study was to investigate the impact that the decision to outsource the internal auditing function had in the South African private and public organisations. In this regard two research objectives were identified:

- to establish the motivation behind the decision to outsource the internal audit function

- to examine the impact that the decision to outsource the internal auditing function has on both auditors' independence (internal and external) and the quality of the internal audit service.

A comparative study of a quantitative nature was conducted within the framework of a descriptive research study. Accordingly, the IIASA distributed an electronic questionnaire via 
their newsletter. This method was used in order to attract a good response rate. Subsequently, the questionnaire was distributed to a purposive sample of 80 South African organisations from both the public and private sector. In addition, questionnaires were distributed and individuals approached at IIASA regional events. Organisations in the public sector that were included in the study comprised a combination of government departments, government agencies and provincial departments. Organisations in the private sector comprised companies listed on the JSE Ltd, as well as influential unlisted private companies. Selim and Yiannakas (2000:13) found this method to be the most effective vehicle for reaching a significant number of respondents.

\section{DISCUSSION AND RESULTS}

The results of the survey are discussed in this section to support the objectives of the study, using the evaluation methods used by Selim and Yiannakas (2000), and are divided into two main categories: basic frequencies and associations between categorical variables. Basic frequency tables were used to present the results of the questionnaire regarding the organisation's consideration of outsourcing the whole or part of their internal auditing function by sector, the duration of this outsourcing, the level of satisfaction with the quality of the service provided by sector, factors affecting the decision to outsource, the proportion of the internal audit service hours provided by external service providers versus external and internal providers combined, and the percentage breakdown of outsourced internal auditing hours by activity.

Of the entire purposive sample approached, 72 organisations responded. These respondents comprised chief audit executives (CAEs), internal auditors, senior managers and managers, with the majority of respondents occupying the position of CAE or equivalent. In instances where more than one survey was completed by an organisation, only one questionnaire (the questionnaire completed by the most senior staff member in the organisation) was included in the study, as the research unit of the study was defined as an organisation. Although questionnaires were primarily addressed to CAEs and financial directors (FDs), it is interesting to note that in some instances the surveys were delegated to senior managers, managers and internal auditors to complete.

Respondents were asked whether they had at any stage considered outsourcing the whole or part of their internal auditing function. As reflected in TABLE 3, 22.2\% of respondents had considered outsourcing this function. This figure can be broken down into $17.2 \%$ of public sector and $26.2 \%$ of private sector respondents that had considered outsourcing their internal auditing function. In addition, there appeared to be no significant difference in the consideration of outsourcing of the internal auditing function by sector. This can be supported by the use of the chi-square $\chi^{2}=$ $0.552, p$-value $=.458$ and Fisher's exact $p$-value $=.556$ significance tests. This deviated from Selim and Yiannakas's (2000:219) study, which found that there were significant differences between respondents in the private and public sectors. "This difference between the two sectors can be explained, to a certain extent, by the fact that government departments - in an effort to achieve the best value for money for the taxpayer - market test on a regular basis, among other activities, the internal auditing function" (Selim \& Yiannakas, 2000:219), which is not the case in South Africa. 
TABLE 3: Organisation's consideration of outsourcing the whole or part of their internal auditing function by sector

\begin{tabular}{lcccccc}
\hline & Count & $\begin{array}{c}\text { \% within } \\
\text { sector }\end{array}$ & Count & $\begin{array}{c}\text { \% within } \\
\text { sector }\end{array}$ & Count & \% of Total \\
\cline { 2 - 7 } Yes & 5 & 17.2 & 11 & 25.6 & 16 & 22.2 \\
No & 18 & 62.1 & 25 & 58.1 & 43 & 59.7 \\
N/A & 6 & 20.7 & 7 & 16.3 & 13 & 18.1 \\
\hline Total & 29 & 100 & 43 & 100 & 72 & 100 \\
\hline
\end{tabular}

Source: Authors' analysis

i: chi-square $(\chi 2)=0.552, p$-value $=.458$; Fisher's exact $p$-value $=.556$ (significance tests do not include N/A)

The respondents whose organisations fully, partially or co-source their internal auditing function were required to provide information as to when the organisation had started doing so. As can be seen from TABLE 4, responses varied with $37.5 \%$ of organisations stating that they do outsource, indicating that this had occurred for the past ten years or less. A further analysis of this statistic reveals that $12.5 \%$ of respondents had been outsourcing their internal auditing function for between one and five years and $6.9 \%$ of respondents for more than five years. TABLE 4 shows that outsourcing the internal auditing function is a relatively new phenomenon in the South African context; this is further supported by the $18.1 \%$ of respondents who have had established outsourcing arrangements for less than a year. The reason for this is the issuance of the revised King III code for corporate governance in South Africa, which strongly recommends the establishment of an internal auditing function in some form or another (I0D, 2009).

TABLE 4: Duration of outsourcing the internal auditing function

\begin{tabular}{lcc}
\hline & Count & \% of Total \\
\hline Less than l year & 13 & $18.1 \%$ \\
$1-5$ years & 9 & $12.5 \%$ \\
$6-10$ years & 5 & $6.9 \%$ \\
$\mathrm{~N} \backslash \mathrm{A}$ & 41 & $56.9 \%$ \\
Not answered & 4 & $5.6 \%$ \\
\hline Total & 72 & $100.0 \%$ \\
\hline
\end{tabular}

Source: Authors' analysis

Further analysis was done by asking respondents to disclose their level of agreement, giving various reasons that would motivate the organisation to outsource its internal auditing function. A Likert scale was used as a measurement tool with $-2=$ strongly disagree, $-1=$ disagree, 0 = neutral, +1 = agree and +2 = strongly agree.

It was found that public sector organisations were significantly more likely to agree that legal liability insurance of outside service providers (OSPs) (significant at the $5 \%$ level) and 
scheduling flexibility or time management (marginally significant or at the $10 \%$ level) were reasons for outsourcing of the internal auditing function (see TABLE 5).

TABLE 5: Level of agreement with reasons to outsource the internal auditing function

\begin{tabular}{lccccc}
\multicolumn{1}{c}{ Reason } & Count & Mean & Median & Mode & $\begin{array}{c}\text { p-value } \\
\text { (public versus } \\
\text { private) }\end{array}$ \\
\hline Expertise of OSP & 45 & 1.29 & 2.00 & 2.00 & 0.8713 \\
$\begin{array}{l}\text { Legal liability insurance of OSP } \\
\begin{array}{l}\text { Scheduling flexibility/time } \\
\text { management }\end{array}\end{array}$ & 47 & 0.51 & 0.00 & 0.00 & 0.0082 \\
$\begin{array}{l}\text { Reduce overall cost of internal } \\
\text { audit }\end{array}$ & 47 & 0.49 & 0.00 & 0.00 & 0.0637 \\
\begin{tabular}{l} 
Improve internal audit quality \\
\hline
\end{tabular} & 45 & 0.78 & 1.00 & 1.00 & 0.1158 \\
\hline
\end{tabular}

Source: Authors' analysis

i: Using Wilcoxon rank sum test to ascertain whether there were significant differences in the distribution of response scores to these criteria by sector

In South Africa, the significance of maintaining independence in the provision of internal audit services for companies is governed legislatively by both section 93 of the Companies Act of 2008 and the Auditing Professions Act of 2005. The provision of internal audit services is designated as the provision of a non-assurance service by auditors.

The Companies Act 71 of 2008 does not prohibit the provision of both internal and external audit services by the same audit firm; however, in terms of section 94(7)(e): "The audit committee of a company has to determine the nature and extent of any non-audit services that the auditor may provide to the company and to pre approve any proposed agreement with the auditor for the provision of non audit services to the company" (SAICA:2011). The onus therefore rests on the audit committee of the company to evaluate the independence of the auditors and to approve the provision of internal audit work by the auditing firm. The provision of both assurance and non-assurance work by the auditing firm would also be contrary to the King III report on corporate governance.

An auditor providing both an internal auditing service and the external audit would be reevaluating his own work. Accordingly, the Auditing Profession Act lays down certain regulations that have to be complied with by all registered auditors in South Africa. Section 44(6) of this Act states: "A registered auditor may not conduct the audit of any financial statements of an entity, whether as an individual registered auditor or as a member of a firm if the registered auditor has or had a conflict of interest in respect of that entity, as prescribed by the Regulatory Board" (SAICA, 2011). Safeguards may be implemented to reduce the risk of self-review to an acceptably low level, the most practical of which would be to ensure that separate engagement teams are used to provide the different services.

Respondents were asked to indicate where applicable whether their organisation used the same service provider for both internal and external auditing services. The unanimous response was that this practice is not applied. 
The code of ethics of the International Federation of Accountants (IFAC), which has been adopted by the South African Institute of Chartered Accountants (SAICA), reinforces this principle by stating that professional accountants in public practice must remain independent, and therefore should not undertake an engagement which would threaten this independence.

When asked about the level of satisfaction with the quality of the service provided, it was observed that in both sectors respondents were generally satisfied. As indicated in TABLE 6, no statistically significant difference was observed between sectors.

However, two of the respondents indicated that they were very dissatisfied with the quality of the service provided and one of the respondents added the following comment: "We have only recently gone solely in-house. In my opinion it was wasteful expenditure in terms of PFMA, someone should have been charged. They were not utilised correctly and cost us a lot of money that could be used more fruitfully. I am also of the opinion that they sometimes are out to make a 'quick buck' and integrity is often compromised."

TABLE 6: Level of satisfaction with the quality of the provided service by sector

\begin{tabular}{lcccccc}
\hline & Count & $\begin{array}{c}\text { \% within } \\
\text { sector }\end{array}$ & Count & $\begin{array}{c}\text { \% within } \\
\text { sector }\end{array}$ & Count & \% of Total \\
\hline Very dissatisfied & 1 & 3.3 & 1 & 2.4 & 2 & 2.8 \\
Dissatisfied & 1 & 3.3 & 1 & 2.4 & 2 & 2.8 \\
Uncertain & 8 & 26.7 & 9 & 21.4 & 17 & 23.6 \\
Satisfied & 18 & 60.0 & 19 & 45.2 & 37 & 51.3 \\
Very satisfied & 1 & 3.3 & 3 & 7.1 & 4 & 5.6 \\
N/A & 1 & 3.3 & 9 & 21.4 & 10 & 13.9 \\
\hline Total & 30 & 100 & 42 & 100 & 72 & 100 \\
\hline
\end{tabular}

Source: Authors'analysis

i: Fisher's exact $p$-value $=.244$ (note: significance tests do not include N/A)

An organisation's decision to outsource the internal auditing function is dependent on a number of factors, including the confidentiality of information, scheduling flexibility/time management and a reduction in the total auditing costs. The relevance of these factors was investigated by asking respondents to indicate the importance they attach to each of them using a five-point Likert scale (where $1=$ not relevant, $2=$ not important, 3 = important, 4 =very important, and 5 = extremely important).

An analysis of the results contained in TABLE 7 makes it clear that confidentiality of information was rated as a very important factor by the majority of respondents. In addition, the scheduling flexibility/time management was noted as being important to organisations in deciding to outsource their internal auditing function. With respect to the factors that are important to both sectors, no significant differences were found in the distribution of importance scores for the criteria used in the decision to outsource by sector (see TABLE 7). However, a marginally significant difference $(p$-value $=0.0573)$ was identified for reduction in total auditing costs, with the public sector organisations generally ranking this as being more important as a 
deciding factor for outsourcing than organisations in the private sector (a mean of 2.31 and 1.89 respectively).

TABLE 7: Factors affecting the decision to outsource the internal auditing function and significance differences between sectors

\begin{tabular}{|c|c|c|c|c|c|}
\hline Factor & Count & Mean & Median & Mode & $\begin{array}{l}p \text {-value i(public } \\
\text { versus private }\end{array}$ \\
\hline Confidentiality information & 67 & 2.70 & 3.00 & 4.00 & 0.5263 \\
\hline $\begin{array}{l}\text { Alignment of organisational } \\
\text { culture }\end{array}$ & 67 & 2.49 & 3.00 & 2.00 & 0.2467 \\
\hline $\begin{array}{l}\text { Scheduling of flexibility/time } \\
\text { management }\end{array}$ & 67 & 1.99 & 2.00 & 3.00 & 1.0000 \\
\hline $\begin{array}{l}\text { Reduction of internal audit } \\
\text { cost }\end{array}$ & 67 & 1.96 & 2.00 & 2.00 & 0.1529 \\
\hline Reduction of external cost & 67 & 2.07 & 2.00 & 2.00 & 0.9582 \\
\hline Reduction of total audit cost & 67 & 2.07 & 2.00 & 2.00 & 0.0573 \\
\hline
\end{tabular}

Source: Authors' analysis

Respondents were asked to say approximately how many hours were devoted to internal audit services by external service providers as opposed to internal service providers. An analysis of the results shown in TABLE 8 indicates that private sector organisations were significantly $(p<.001)$ more likely to have longer hours provided by internal service providers relative to external service providers when compared to public sector organisations.

TABLE 8: Proportion of internal audit service hours provided by external service providers versus external and internal service providers combined

\begin{tabular}{|c|c|c|c|c|c|c|}
\hline Category & Count & Mean & $\begin{array}{c}\text { Standard } \\
\text { error }\end{array}$ & $\begin{array}{l}\text { Standard } \\
\text { deviation }\end{array}$ & $95 \% \mathrm{Cl}$ & $p$-value $i$ \\
\hline Overall & 53 & 0.20 & 0.04 & 0.27 & $0.12, \quad 0.27$ & - \\
\hline Public & 22 & 0.37 & 0.07 & 0.34 & $0.22,0.52$ & - \\
\hline Private & 31 & 0.07 & 0.02 & 0.12 & $0.03, \quad 0.12$ & - \\
\hline $\begin{array}{l}\text { Difference (public } \\
\text { vs private) }\end{array}$ & - & -0.30 & 0.07 & - & $-0.42,-0.16$ & $<0.001$ \\
\hline
\end{tabular}

Source: Authors'analysis

i: test $p$-value with null hypothesis that the mean difference is equal to zero

Respondents were further asked to indicate the percentage breakdown of outsourced internal audit hours by activity, as indicated in TABLE 9 . The largest percentage of hours of outsourced internal audit by activity was attributed to internal control evaluation (20.8\%), followed by routine internal auditing functions (19.5\%) and electronic data processing (EDP) auditing (16.6\%). The statistical analysis also highlighted the following findings regarding the level of 
outsourcing of the internal auditing function planned for the 2010 financial year, with the majority of respondents indicating that they would maintain the current level of such outsourcing $(37.5 \%)$, followed by an indication by $29.2 \%$ of respondents that they intended to decrease their current level. A small minority indicated that this level would be increased $(5.6 \%)$, while the remainder $(27.7 \%)$ did not respond or indicated that this question was not applicable to their organisation. No significant difference was observed between public and private organisations with regard to changes in the level of internal audit outsourcing in the 2010 financial year (Fisher's exact $p$-value $=.271$ ).

TABLE 9: Percentage breakdown of outsourced internal audit hours by activity

\begin{tabular}{lccc}
\hline Activity & Count & Mean (standard deviation) & Min-Max \\
\hline Financial statement audits of subsidiaries & 53 & $5.06(14.25)$ & $0-100$ \\
Special consulting projects & 52 & $6.11(11.05)$ & $0-55$ \\
Routine internal audits & 52 & $19.46(24.38)$ & $0-100$ \\
EDP auditing & 52 & $16.60(25.62)$ & $0-100$ \\
Internal control evaluation & 53 & $20.75(25.16)$ & $0-100$ \\
Other & 41 & $5.83(18.78)$ & $0-9$ \\
\hline
\end{tabular}

Source: Authors' analysis

An alarming finding was that the majority of organisations indicated that they did not view internal auditing as a training ground ( $57.1 \%$ with $95 \% \mathrm{Cl}: 44.05-69.50 \%)$. As can be seen by the $95 \%$ binomial confidence interval, the lower limit is less than $50 \%$, so it cannot be said that this view was significant based on the non-random sample used. In addition, no significant difference was found between organisations in the public and private sector $(p$-value $=0.268)$.

\section{CONCLUSION}

This research was undertaken to determine the extent to which the internal auditing function is currently outsourced in South African private and public sector organisations. This was done by surveying financial directors and CAEs, among others, in both the public and the private sectors in order to determine their perceptions on the outsourcing of this function. Issues that were investigated include establishing the rationale for outsourcing the internal auditing function, and examining the impact that the decision to outsource this function has both on auditors' independence (internal and external) and on the quality of the internal audit service.

This study analysed the data collected through a survey and found that larger organisations with 1000 or more employees appear to be less likely to have outsourced internal auditing services in the past year than smaller organisations. A statistical analysis revealed that there appeared to be no significant difference in the consideration of outsourcing the internal auditing function by sector. The rationale supporting these findings confirmed that the private sector was significantly (Fisher's exact $p$-value of 0.015$)$ more likely to consider internal audit a core activity than the public sector ( 65.9 versus $40 \%$ ), while the public sector was more uncertain (36.7 versus $9.8 \%$ ). 
The findings confirmed that $22.2 \%$ of respondents had considered outsourcing their internal auditing function. Of these, $17.2 \%$ related to the public sector and $26.2 \%$ to the private sector. Accordingly, there appears to be no significant difference in the consideration of outsourcing of internal auditing function by sector. The length of time (duration) for which the internal auditing function is outsourced varied, with $37.5 \%$ of respondents stating that they had outsourced for the past ten years or less. Of these, $12.5 \%$ of respondents had been outsourcing their internal auditing function for between one and five years, $6.9 \%$ had been outsourcing for more than five years and $18.1 \%$ had had outsourcing arrangements in place for less than a year. It has therefore become evident that outsourcing of the internal auditing function is a relatively new phenomenon in South Africa.

It was also found that public sector organisations were significantly more likely to agree that legal liability insurance of outside service providers (OSPs) (significant at the $5 \%$ level) and scheduling flexibility or time management (marginally significant or at the $10 \%$ level) were reasons for outsourcing the internal auditing function. The results confirmed that respondents in both sectors were generally satisfied with the quality of the service provided.

In addition, confidentiality of information was rated as a very important factor by the majority of respondents, with the scheduling of flexibility/time management also being noted as important to organisations in deciding to outsource their internal auditing function. Interactions with the external auditor also do not differ significantly between the two sectors. No significant differences were observed between sectors with regard to interaction with external auditors in terms of the coordination of areas of audit coverage and work schedule.

The majority of organisations for which data was available indicated that external auditors had access to work papers; moreover, all respondents without exception indicated that they had access to reports. Codified governance reforms combined with legislation mitigated the threat to independence and respondents clearly indicated that the same provider for external auditing services did not provide their internal audit services.

The time spent on different internal auditing activities varied across both sectors, although private organisations were significantly more likely to have longer hours provided by internal service providers relative to outside providers than the public sector, with the largest percentage of hours of outsourced internal auditing by activity being attributed to internal control evaluation followed by routine internal auditing function and EDP auditing.

The results provide insight into the dynamics of outsourcing arrangements in South Africa's private and public sector organisations. The study provided a good comparison with the Selim and Yiannakas (2000) study, which was conducted in the United Kingdom, and brings to light the way in which developing economies strategise in order to provide world-class services with a limited pool of skills.

The limitations of the study were, firstly, that the sample size was relatively small, particularly if both the private sector and the public sector are viewed in isolation. Secondly, owing to the nature of surveys, an inherent limitation was the fact that the results were based on the perceptions of respondents and therefore misinterpretation of the questions as well as the objectivity in the responses may be questioned. Finally, corroboration in the form of interviews would have been useful in supporting the conclusions drawn. Despite these limitations, the study made a valuable contribution in understanding the dynamics involved when outsourcing of the internal audit function and independence in both sectors of the South African environment. 
Future academic research in South Africa could extend to examining the demand for chief internal auditors (CIAs) versus the chartered accountants (CA (SA)) in South Africa, who, according to the proposed South African Institute of Chartered Accountants competency framework, are now also being trained to develop internal auditing as a residual skill. Other aspects of internal auditing, such as the extent of consulting work compared to assurance activities, could be explored further, or the same research could be conducted on a much broader scale. Academic research could focus on developing a core curriculum to address the

\section{LIST OF REFERENCES}

Adams, M.B. (1994). Agency theory and the internal audit. Managerial Auditing Journal, 9(8), pp. 812.

Allegrini, M., D’Onza, G., Paape, L., Melville, R. \& Sarens, G. (2006). The European literature review on internal auditing. Managerial Auditing Journal, 21 (8), pp. 845-853.

Arnold, D.F., Bernardi, R.A. \& Neidermeyer, P.E., (1999). The effect of independence on decisions concerning additional audit work: A European perspective. Auditing: A Journal of Practice \& Theory, Supplement, 18.

Bahli, B. \& Rivard, S., (2010). The information technology outsourcing risk: A transaction cost and agency theory-based perspective. Journal of Information Technology, 18(3), pp. 211-221.

Baker, G., Gibbons, R. \& Murphy, K.J. (2002). Relational contracts and the theory of the firm. The Quarterly Journal of Economics, 117(1), pp. 39-84.

Blumberg, D.F. (1998). Strategic assessment of outsourcing and downsizing in the service market. Managing Service Quality, 8, pp. 5-18.

Carcello, J.V., Hermanson, D.R. \& Raghunandan, K. (2005). Factors associated with US public companies' investment in Internal Auditing. Accounting Horizons, 19(2), pp. 69-84.

Carey, P., Subramanium, N. \& Ching, K.C.W. (2006). Internal audit outsourcing in Australia. Accounting and Finance, 46, pp. 11-30.

Castanheira, N., Rodrigues, L.L. \& Craig, R. (2009) Factors associated with the adoption of risk-based Internal Auditing. Managerial Auditing Journal, 25(1), pp. 79-98.

Cooper, B., Leung, P. \& Wong, G. (2006). The Asia Pacific literature review on internal auditing. Managerial Auditing Journal, 21 (8), pp. 822-834.

Eisenhardt, K.M., (1989). Agency theory: An assessment and review. The Academy of Management Review, 14(1), pp. 57-74.

Espino-Rodriguez, T.F. \& Padrón-Robaina, V. (2006) A review of outsourcing from the resource-based view of the firm. International Reviews of Management Reviews, 26(1), pp. 49-70.

Geiger, M.A., Lowe, D.J. \& Pandy, K.T. (2002). Outsourced internal audit services and the perception of auditor independent. The CPA Journal, 72(4), pp. 20-24.

Gilley, K.M. \& Rasheed, A. (2000). Making more by doing less: Analysis of outsourcing and its effects on firm performance. Journal of Management, 26, pp. 763-790.

Goodwin, J. \& Kent, P. (2004). Factors affecting the voluntary use of internal audit. Working Paper University of Queensland. Queensland University of Technology, No. 2004-001. 
Gottschalk, P. \& Solli-Sæther, H. (2005). Critical success factors from IT outsourcing theories: An empirical study. Industrial Management \& Data Systems, 105(6), pp. 685-702.

Greaver II, M.F. (1999). Strategic outsourcing: A structured approach to outsourcing decisions and initiatives. New York: Amacon.

Harrigan, K. (1985). Strategies for intra-firm transfers and outside sourcing. Academy of Management Journal, 28, pp. 914-925.

Harrington, C. (2004). Internal audit's new role: Put together a top-notch department. [Online] Available: www.journalofaccountancy.com [Accessed 12 January 2011].

Hass, S., Abdolmohammadi, M.J. \& Burnaby, P. (2006). The Americas literature review on internal auditing. Managerial Auditing Journal, 21 (8), pp. 835-844.

Hill, C.L. \& Booker, Q. (2004). State accountancy regulators' perceptions of independence of external auditors when performing internal audit activities for non-public clients. Research paper, Department of Accounting, Jackson State University.

iKUTU Research Team. (2010). Institute of Internal Auditors (IIASA). iKutu Brochure Investigation. Institute of Internal Auditors South Africa.

Institute of Directors (IOD). (1994). King Report on Corporate Governance for South Africa. King Committee on Corporate Governance.

Institute of Directors (IOD). (2009). King Report on Corporate Governance for South Africa. King Committee on Corporate Governance.

Institute of Internal Auditors Inc. (IIA). (2009). The role of internal auditing in resourcing the internal audit activity. IIA Position Paper (email correspondence from IRavenscroft@mercantile.co.za, 26 April 2011).

Institute of Internal Auditors (IIA). (2011). Standards for the professional practice of internal auditing. [Online] Available: http://www.theiia.org/ecm/guide-frame. (Accessed 18 November 2011.

Lei, D. \& Hitt, M. (1995). Strategic restructuring and outsourcing: the effect of mergers and acquisitions and LBOs on building skills and capabilities. Journal of Management, 21, pp. 835-859.

Liang, T. \& Huang, J., (1998). An empirical study on consumer acceptance of products in electronic markets: a transaction cost model. Decision Support Systems, 24, pp. 29-43.

Loh, L. \& Venkatraman, N. (1992). Determinants of information technology outsourcing: A cross sectional analysis. Journal of Management Information Systems, 9, pp. 7-24.

McCarthy, I.P. \& Anagnostou, A. (2004). The impact of outsourcing on the transaction costs and boundaries of manufacturing. International Journal of Production Economics, 88, pp. 61-71.

Mclvor, R. (2000). A practical framework for understanding the outsourcing process. Supply Chain Management: An International Journal, 5(1), pp. 22-36.

Mol, M.J., Van Tulder, R.J.M. \& Beije, P.R. (2005). Antecedents and performance consequences of international outsourcing. International Business Review, 14, pp. 599-617.

Ngwenyama, 0.K. \& Bryson, N. (1999). Making the information systems outsourcing decision: A transaction cost approach to analyzing outsourcing decision problems. European Journal of Operational Research, 115, pp. 351-367.

Quélin, B. \& Duhamel, F. (2003). Bringing together strategic outsourcing and corporate strategy: Outsourcing motives and risks. European Management Journal, 21, pp. 647-661. 
Quinn, J.B. \& Hilmer, F.G. (1994). Strategic outsourcing. Sloan Management Review, Summer, pp. 4355 .

Reed, D. (2002). Employing normative stakeholder theory in developing countries: A critical theory perspective. Business Society, 41(2), pp. 166-207.

Rothery, B. \& Robertson, I. (1996). Outsourcing. México: Editorial Limusa.

SAICA Legislation Handbook 2011/12. (2011). Companies Act 2008. Vol. 1. Pietermaritzburg: Lexis Nexis.

Selim, G. \& Yiannakas, A. (2000). Outsourcing the Internal Audit Function: A survey of the UK public and private sectors. International Journal of Auditing, 4, pp. 213-226.

Smith, J.A., Morris, J. \& Ezzamel, M. (2005). Organisational change, outsourcing and the impact on management accounting. Research Paper, Cardiff Business School, Cardiff University.

Sutton, M.H. (1997). Auditor independence: The challenge of fact and appearance. Accounting Horizons, $11(1)$, p. 86.

Van Peursem, K. \& Jiang, L. (2008). Internal audit outsourcing and rationales: SME evidence New Zealand. Asian Review of Accounting, 16(3), pp. 219-245. 